\title{
LEAF AND STEM CHEMICAL COMPOSITION OF DIVERGENT ALFALFA CULTIVARS
}

\author{
D. Milić, Đ. Karagić, S. Vasiljević, A. Mikić, B. Mijić, S. Katić \\ Institute of Field and Vegetable Crops, 21000 Novi Sad, Republic of Serbia \\ Corresponding author: dragan.milic@ifvens.ns.ac.rs \\ Original scientific paper
}

Abstract: Alfalfa is a perennial crop that provides a higher yield of proteins per unit area than any field crop, which makes it highly desirable for the production of hay and feed for domestic animals (especially ruminants). The objective of this study was to determine the dry matter chemical composition in the whole plant, leaves and stems of five divergent alfalfa cultivars. Variations were found in the contents of proteins, hemicellulose, NDF, ADF, ADL, cellulose, and minerals depending on genotype and plant part. Significant differences existed between the cultivars in quality parameters, indicating that breeding for high alfalfa quality is justifiable.

Key words: alfalfa, proteins, fibers, minerals, cultivar, leaves, stems.

\section{Introduction}

Alfalfa (Medicago sativa L.) is a major forage legume worldwide. In Serbia, it is in the third place according to acreage (200.000 ha), after corn and small grains. Alfalfa produces more protein per hectare than grain or oilseed crops; therefore, it is widely used for hay production and as pasture for livestock (Monteros and Bouton, 2009). Alfalfa is a highly valued animal feed. It is a rich source of proteins, fibers, minerals and vitamins used in the diet of livestock, especially ruminants. Alfalfa forage quality is determined by two main components: protein digestibility and protein content (Hill et al., 1988). Digestibility of alfalfa organic matter depends on the contents of cellulose and lignin. As lignin is virtually indigestible, intensive lignification of cell wall in late stages of alfalfa development tends to reduce the coefficient of digestibility.

Protein content in alfalfa dry matter varies from 18 to $25 \%$ depending on the growth stage, cultivar and storage method (Katic et al., 2006). Alfalfa nutritive value is identified with protein content which depends on the share of leaves in dry matter yield which in its turn is positively correlated with protein content (Julier et al., 2001; Katic et al., 2005). The proportion of leaves and stems in alfalfa hay can 
vary greatly, depending on maturity at harvest, handling, and rain damage. For example, alfalfa at early bud may have $600 \mathrm{~g} \mathrm{~kg}^{-1}$ leaves while at early flower, the leaf share declines to $450 \mathrm{~g} \mathrm{~kg}^{-1}$ (Sheaffer et al., 2000). To value alfalfa hay as a biofuel, or as a source of leaf protein, accurate prediction of the proportion of leaf and stem in the hay is necessary (Halgerson et al., 2004). Decreasing protein content is a dilution effect related with the decreasing leaf to stem ratio; the leaves have stable protein content and their protein level is much higher than the protein content in stems. The decline of digestibility is the consequence of two processes: (a) the reduction of the highly digestible component (leaves) because of an increase of the less digestible component (stems) and (b) the decreasing average digestibility of the stem component, with more cell walls (NDF) and lignin (Veronesi et al., 2010).

When determining the nutritive value of alfalfa, ligneous cellulose content should be taken in account in addition to crude protein content. Neutral detergent fiber (NDF) content indicates the intake rate of alfalfa dry matter. The higher the NDF, the lower the alfalfa quality - the content of nutrients is reduced and livestock consumes such alfalfa less readily. In consequence, the livestock grows at a slower rate and the production of livestock products is proportionally reduced. ADF content indicates the potential production energy. Increase in ADF indicates a reduced energy, i.e., reduced quality (Katić et al., 2008). Forms of energy derived from cellulose hay are not effectively used as livestock feed. Because alfalfa plants accumulate increasing rates of stem material in total herbage during growth, the poor quality of stems becomes a greater issue in more mature alfalfa (Sheaffer et al., 2000).

Significant differences were registered in the contents of crude fiber, ADF and NDF that were caused by genetic factors (Katić et al., 2008). Furthermore, Sheaffer et al. (1998) obtained significant differences in the contents of NDF and ADF between low-, medium- and high-quality alfalfa cultivars.

The content of minerals in alfalfa fully meets the livestock requirements while the content of fats is low (averaging $3.8 \mathrm{~g} / \mathrm{kg}$ ), and it varies slightly among cultivars (Katić et al., 2009).

The objective of this study was to determine the chemical composition of dry matter in leaves, stems and whole plants of five divergent alfalfa cultivars.

\section{Materials and Methods}

Forage quality was studied in five alfalfa cultivars of different geographic origin, developed by different breeding methods and for different purposes: NS Banat ZMS II (Serbia), Ghareh Yon Geh (Iran), Zuzana (Czech Republic), Pecy (France) and RSI 20 (Spain).

Field trials in five replicates were conducted in 2006 at the experiment field of Institute of Field and Vegetable Crops in Novi Sad. 
Chemical analyses were performed on samples taken in the third year of crop life (2008). Samples from the first cut were used for a whole plant analysis and from first and second cuts for leaf and stem analyses. Samples for the whole plant analysis were taken from spaced plants of all genotypes. Sample weight was $500 \mathrm{~g}$ of green forage. Plant materials were dried at $60^{\circ} \mathrm{C}$ for about 48 hours. Chemical analyses were performed in Laboratory for Soil and Agroecology of Institute of Field and Vegetable Crops in Novi Sad. The analyses were carried out using standard methods, namely, the AOCS-approved Ba 6a-05 procedure for crude fiber (CF) and the Filter Bag Technique (Ankom Technology Corp., Fairport, $\mathrm{NY}$ ). for neutral detergent fiber (NDF), acid detergent fiber (ADF), and acid detergent lignin (ADL). The analyses were performed on an Ankom 2000 Fiber Analyzer (Ankom Technology Corp., NY, USA).

The crude protein content, mineral substances and oil content $\left(\mathrm{g} \mathrm{kg}^{-1}\right)$ were determined using the standard chemical analysis proposed by Kjeldahl. Oil and ash contents were determined only in leaves and stems.

The two-factorial analysis of variance was used, with cultivar as factor A and cut as factor B. The LSD test was used for testing the significance of differences.

\section{Results and Discussion}

The studied cultivars differed significantly in crude protein content. Cultivars Pecy, Zuzana and RSI 20 had higher crude protein contents than cultivars NS Banat ZMS II and Ghareh Yon Geh (Table 1).

Table 1. Quality parameters for the first cut in 2008 , in whole alfalfa plants

\begin{tabular}{|l|c|c|c|c|c|c|}
\hline Cultivar & $\begin{array}{c}\text { Protein } \\
\mathrm{g} \mathrm{kg}^{-1}\end{array}$ & $\begin{array}{c}\mathrm{ADF} \\
\mathrm{g} \mathrm{kg}^{-1}\end{array}$ & $\begin{array}{c}\mathrm{NDF} \\
\mathrm{g} \mathrm{kg}^{-1}\end{array}$ & $\begin{array}{c}\mathrm{ADL} \\
\mathrm{g} \mathrm{kg}^{-1}\end{array}$ & $\begin{array}{c}\text { Hemicellulose g kg } \\
\text { (NDF-ADF) }\end{array}$ & $\begin{array}{c}\text { Cellulose g kg } \\
\text { (ADF-ADL) }\end{array}$ \\
\hline NS Banat ZMS II & 202.0 & 398.0 & 455.7 & 107.0 & 57.7 & 291.0 \\
\hline Ghareh Yon Geh & 184.0 & 416.7 & 442.7 & 113.0 & 26.0 & 303.7 \\
\hline Zuzana & 206.0 & 413.0 & 434.0 & 92.3 & 21.0 & 320.7 \\
\hline Pecy & 209.0 & 397.7 & 421.3 & 99.0 & 23.7 & 298.7 \\
\hline RSI 20 & 206.0 & 388.0 & 412.0 & 92.0 & 24.0 & 296.0 \\
\hline Average & 201.0 & 402.7 & 433.1 & 100.7 & 30.5 & 302.0 \\
\hline CV \% & 6.0 & 2.5 & 2.3 & 3.1 & 9.5 & 3.8 \\
\hline \multicolumn{1}{c}{0.05} & 23.0 & 19.2 & 18.7 & 5.9 & 5.4 & 21.7 \\
LSD 0.01 & 33.0 & 28.0 & 27.2 & 8.6 & 7.9 & 31.6 \\
\hline
\end{tabular}

The cultivars differed significantly in the fiber content for the whole plant. Cultivars NS Banat ZMS II and Ghareh Yon Geh had highest contents of neutral fibers, i.e., highest dry matter intake rates. Cultivar Ghareh YonGeh had highest contents of ADF and ADL. At the whole plant level, cultivar RSI 20 had lowest 
NDF, ADF and ADL contents and the highest energy value of dry matter (Table 1). Also at the whole plant level, the coefficients of variation for crude protein and hemicellulose contents were $6 \%$ and $9.5 \%$, respectively, while the other quality components showed relatively low variations $(2.5 \%-3.8 \%)$.

The analysis of quality components in the leaf emphasized the importance of foliage preservation during storage of alfalfa hay or haylage. Leaves accumulate high contents of crude proteins and minerals (287.7 and $110.7 \mathrm{~g} \mathrm{~kg}^{-1}$, respectively). Also, the fiber content (cellulose, hemicellulose, NDF, ADF and ADL) is significantly lower in alfalfa leaves than in stems (Table 2). In this study, cultivar Pecy had the highest protein content in leaves (297.4 $\mathrm{g} \mathrm{kg}^{-1}$ ), which was significantly higher than those found in cultivars Ghareh Yon Geh and NS Banat ZMS II (272.3 and $279.3 \mathrm{~g} \mathrm{~kg}^{-1}$, respectively). Highest contents of NDF, ADF and minerals in leaves were found in cultivar Ghareh Yon Geh (Table 2). There were no significant differences among the cultivars in the ligneous cellulose complex (except for the NDF content) and oil contents in leaves. The cultivars differed significantly in the content of minerals in leaves (Table 2). The lowest content of minerals was recorded in cultivar Pecy $\left(99.1 \mathrm{~g} \mathrm{~kg}^{-1}\right)$.

Table 2. Quality parameters for the first and second cut in 2008 (average), in alfalfa leaves

\begin{tabular}{|l|c|c|c|c|c|c|c|c|}
\hline Cultivar & $\begin{array}{c}\text { Protein } \\
\mathrm{g} \mathrm{kg}^{-1}\end{array}$ & $\begin{array}{c}\text { NDF } \\
\mathrm{g} \mathrm{kg}^{-1}\end{array}$ & $\begin{array}{c}\text { ADF } \\
\mathrm{g} \mathrm{kg}^{-1}\end{array}$ & $\begin{array}{c}\text { ADL } \\
\mathrm{g} \mathrm{kg}^{-1}\end{array}$ & $\begin{array}{c}\text { Oil } \\
\mathrm{g} \mathrm{kg}^{-1}\end{array}$ & $\begin{array}{c}\text { Ash } \\
\mathrm{g} \mathrm{kg}^{-1}\end{array}$ & $\begin{array}{c}\text { Hemicellulose g kg } \\
\text { (NDF-ADF) }\end{array}$ & $\begin{array}{c}\text { Cellulose g kg } \\
\text { (ADF-ADL) }\end{array}$ \\
\hline NS Banat ZMS II & 279.3 & 173.7 & 137.6 & 45.4 & 20.8 & 108.8 & 36.0 & 92.2 \\
\hline Ghareh Yon Geh & 272.3 & 190.4 & 153.8 & 38.5 & 17.8 & 125.1 & 36.5 & 115.3 \\
\hline Zuzana & 294.7 & 176.6 & 153.1 & 33.3 & 23.9 & 102.0 & 23.5 & 119.8 \\
\hline Pecy & 297.4 & 178.8 & 142.8 & 37.6 & 24.2 & 99.1 & 36.0 & 105.2 \\
\hline RSI 20 & 291.9 & 171.3 & 145.2 & 40.5 & 21.8 & 118.4 & 26.1 & 104.6 \\
\hline Average & 287.1 & 178.1 & 146.5 & 39.1 & 21.7 & 110.7 & 31.6 & 107.4 \\
\hline CV \% & 7.1 & 1.0 & 2.7 & 20.2 & 16.8 & 4.6 & 11.5 & 6.4 \\
\hline \multicolumn{1}{|c|}{0.05} & 18.4 & 14.9 & 29.4 & 21.9 & 10.0 & 13.9 & 25.7 & 38.3 \\
LSD 0.01 & 24.7 & 20.0 & 39.5 & 36.3 & 13.4 & 18.7 & 34.5 & 51.4 \\
\hline
\end{tabular}

The coefficients of variation for the contents of crude protein, cellulose, hemicellulose and oil in leaves of the analyzed alfalfa genotypes were $7.1 \%, 6.4 \%$ $11.5 \%$ and $16.8 \%$ respectively. Highest variations in leaves were registered for the content of ADL (20.2\%). The coefficients of variation for NDF, ADF and ash in leaves were low.

Quality traits of the stem indicated that alfalfa stems had a significantly lower nutritional value than leaves (Table 3), which is consistent with a study of Sheaffer et al. (2000). There were no significant differences in the contents of NDF and ADF, hemicellulose (NDF-ADF), cellulose (ADF-ADL), oil and minerals in stems of the analyzed cultivars.

High coefficients of variation were obtained for the contents of oil and hemicellulose in the stem $(27.2 \%$ and $19.8 \%)$. The contents of ADF varied 
between $5 \%$ and $10 \%$. Low variations were obtained for the contents of NDF and ADL in the stem (Table 3).

Table 3. Quality parameters for the first and second cut in 2008 (average), in alfalfa stems

\begin{tabular}{|l|c|c|c|c|c|c|c|c|}
\hline Cultivar & $\begin{array}{c}\text { Protein } \\
\mathrm{g} \mathrm{kg}^{-1}\end{array}$ & $\begin{array}{c}\mathrm{NDF} \\
\mathrm{g} \mathrm{kg}^{-1}\end{array}$ & $\begin{array}{c}\text { ADF } \\
\mathrm{g} \mathrm{kg}^{-1}\end{array}$ & $\begin{array}{c}\text { ADL } \\
\mathrm{g} \mathrm{kg}^{-1}\end{array}$ & $\begin{array}{c}\text { Oil } \\
\mathrm{g} \mathrm{kg}^{-1}\end{array}$ & $\begin{array}{c}\text { Ash } \\
\mathrm{g} \mathrm{kg}^{-1}\end{array}$ & $\begin{array}{c}\text { Hemicellulose } \mathrm{g} \mathrm{kg}^{-1} \\
\text { (NDF-ADF) }\end{array}$ & $\begin{array}{c}\text { Cellulose g kg } \\
\text { (ADF-ADL) }\end{array}$ \\
\hline NS Banat ZMS II & 109.3 & 583.3 & 504.9 & 118.4 & 8.1 & 48.7 & 78.3 & 386.6 \\
\hline Ghareh Yon Geh & 103.8 & 587.2 & 500.9 & 115.9 & 11.1 & 49.6 & 86.4 & 385.0 \\
\hline Zuzana & 114.3 & 588.2 & 500.8 & 109.0 & 9.9 & 46.9 & 87.5 & 391.8 \\
\hline Pecy & 105.4 & 622.6 & 529.3 & 113.9 & 7.8 & 44.3 & 93.3 & 415.4 \\
\hline RSI 20 & 109.0 & 592.0 & 513.3 & 114.1 & 10.2 & 48.5 & 78.7 & 399.2 \\
\hline Average & 108.4 & 594.7 & 509.8 & 114.3 & 9.4 & 47.6 & 84.8 & 395.6 \\
\hline CV \% & 4.2 & 2.1 & 4.8 & 2.3 & 27.2 & 9.0 & 19.8 & 6.0 \\
\hline \multicolumn{1}{|c|}{0.05} & 10.3 & 35.8 & 46.1 & 8.2 & 8.7 & 5.9 & 52.1 & 43.2 \\
LSD 0.01 & 13.9 & 48.0 & 61.8 & 11.0 & 11.7 & 7.9 & 70.0 & 58.5 \\
\hline
\end{tabular}

Nonsignificant differences existed among the cultivars in crude protein and ADL contents. The highest protein content in the stem was registered in cultivar Zuzana (114.3 $\left.\mathrm{g} \mathrm{kg}^{-1}\right)$, the lowest in cultivar Ghareh Yon Geh $\left(103.8 \mathrm{~g} \mathrm{~kg}^{-1}\right)$. The highest ADL content was found in cultivar NS Banat ZMS II $\left(118.4 \mathrm{~g} \mathrm{~kg}^{-1}\right)$, the lowest in cultivar Zuzana $\left(109.0 \mathrm{~g} \mathrm{~kg}^{-1}\right)$. The difference between them was significant. High lignin content in alfalfa plants increases their resistance to lodging; however, lignin is a major factor that limits cell wall digestibility because it inhibits the digestibility of polysaccharides (Katic et al., 2008).

The coefficients of variation indicated that the variability of the quality traits was not the same in the plant, stems and leaves. Based on variability indicators, the contents of crude protein and cellulose should be monitored in the whole plant. The contents of crude protein, ADL, oil, ash and hemicellulose should be monitored in leaves. However, contents of oil, ash, hemicellulose and cellulose should be monitored in stems.

The results for the quality traits of alfalfa leaves, stems and whole plants obtained in this study are in agreement with those from previous studies (Sheaffer et al. 2000).

The results obtained in this paper confirm those of Veronesi et al. (2010), who claimed that there exist subtle differences between genotypes in the main quality parameters and that alfalfa breeding for increased nutritional value is a viable option.

\section{Conclusion}

The studied alfalfa cultivars varied in the contents of proteins, cellulose, hemicellulose, NDF, ADF, ADL, and minerals depending on genotype and plant part. 
Significant differences existed among the alfalfa cultivars in the nutritional components at the level of the whole plant.

High contents of crude proteins, oil and minerals were registered in alfalfa leaves, while significantly high fiber content (NDF, ADF, ADL, cellulose, hemicellulose) were registered in alfalfa stems.

The obtained results indicated that the quality parameters varied at the levels of the whole plant, leaves and stems.

The results confirmed the importance of alfalfa breeding for high nutritional value. They also indicated that the studied cultivars were a significant source of desirable genes needed for development of alfalfa cultivars with improved quality.

\title{
Acknowledgment
}

This research was financed by the Ministry of Education and Science, Republic of Serbia, project TR 31024: "Increasing the market of forage crops by breeding and optimizing seed production".

\section{Hemijski sastav lišća i stabljika divergentnih sorti lucerke}

\author{
D. Milić, Đ. Karagić, S. Vasiljević, A. Mikić, B. Mijić, S. Katić
}

\section{Rezime}

Lucerka je višegodišnja vrsta koja daje veći prinos proteina po jedinici površine od bilo koje ratarske kulture, pa je zbog toga veoma poželjna za proizvodnju sena i u ishrani domaćih životnja (posebno preživara). Cilj rada je bio da se odredi hemijski sastav suve materije lucerke kod pet divergentenih sorti lucerke u celoj biljci kao i u listu i stabljikama. Lucerka varira u sadržaju proteina, celuloze, hemiceluloze, NDF, ADF, ADL, i mineralnih materija u zavisnosti od genotipa i biljnog dela. Postoje značajne razlike u komponentama hranljive vrednosti lucerke između sorti što ukazuje da oplemenjivanje na veći kvalitet lucerke ima smisla.

\section{References}

HALGERSON L.J., SHEAFFER C.C., MARTIN N. M., PETERSON R.P., WESTON J. S. (2004): Near-Infrared Reflectance spectroscopy prediction of leaf and mineral concentrations in alfalfa. Agron. J. 96, 344-351. 
HILL R.R., JR., SHENK J.S., BARNES R.F. (1988): Breeding for yield and quality. 809-825. In: HANSON A.A. et al. (ed.), Alfalfa and Alfalfa Improvement. ASA-CSSA-SSSA, Madison, Wisconsin.

JULIER B., GUINES F., ECALLE C., HUYGHE C. (2001): From description to explanation of variations in alfalfa digestibility. Proceedings of the XIV Eucarpia Medicago sp. Group Meeting. Zaragoza, 45, 19-23.

JUNG H. G., LAMB J.F.S. (2006): Stem morphological and cell wall traits associated with divergent in vitro neutral detergent fiber digestibility in alfalfa clones. Crop Sci. 46, 2054-2061.

KATIC S., MILIC D., VASILJEVIC S. (2005): Variability of dry matter yield and quality of lucerne genotypes depending on geographic origin. EGF, Grassland Science in Europe, 10, 537-540.

KATIĆ S., MIHAILOVIĆ V., MILIĆ D., KARAGIĆ Đ., VASILJEVIĆ S. (2006): Variation of crude protein content in alfalfa due to genotype and environment. Proceedings of the $2^{\text {nd }}$ COST 852 Workshop Sward Dynamics, N-flows and Forage Utilisation in Legume-Based Systems, Grado, Italy, 10-12 November 2005, 251-255. KATIĆ S., MIHAILOVIĆ V., MILIĆ D., KARAGIĆ Đ., GLAMOČIĆ D., JAJIĆ I. (2008): Genetic and seasonal variations of fibre content in lucerne. Proceedings of the XXVIIth EUCARPIA Symposium on Improvement of Fodder Crops and Amenity Grasses, Copenhagen, Denmark, 19-23 August 2007, 130-135. www.eucarpia.org

KATIĆ S., MILIĆ D., KARAGIĆ Đ. VASILJEVIĆ S., GLAMOČIĆ D., JAJIĆ I. (2009): Variation of protein, cellulose and mineral content of lucerne as influenced by cultivar and cut. Biotechnology in Animal Husbandry, 25, 5-6, 1189-1188.

MONTEROS J.M., BOUTON H.J. (2009). The future of alfalfa and forage crops. Proceedings of the Western Alfalfa \& Forage Conference, December 2-4, 2009, Reno, Nevada.

SHEAFFER C.C., CASH D., EHLKE N.J., HANSEN J.L., HENNING J.C., GRIMSBO JEWETT J., JOHNSON K.D., PETERSON M.A., SMITH M., VIANDS D.R. (1998): Entry x environment interactions for alfalfa forage quality. Agronomy Journal, 90, 774-780.

SHEAFFER C.C., MARTIN N.P., LAMB J.F.S., CUOMO G.R.J., JEWET J. G., QUERING S.R. (2000): Leaf and stem properties of alfalfa entries. Agron. J., 92, 733-739.

VERONESI F., BRUMMER E. C., HUYGHE C. (2010): Alfalfa. 395 - 437. In: BOLLER B., POSSELT U. K., VERONESI F. (eds.): Fodder Crops and Amenity Grasses. Series: Handbook of Plant Breeding, Vol. 5, Springer, New York, USA. 